\title{
Cigarette-Smoke- and Age-Dependent Oxidative Stress Effects in Rats*
}

by

\author{
Thomas Meisgen ${ }^{1}$, Ewald Roemer ${ }^{2}$, Lynda L. Conroy ${ }^{1}$, Jeroen Hostens ${ }^{3}$, Marie Vasquez ${ }^{4}$, Andreas Humeny ${ }^{1}$, Michaela \\ Moehring ${ }^{1}$, Walter K. Schlage ${ }^{1}$, and Michael Kasper ${ }^{5}$
}

${ }^{1}$ Philip Morris International R\&D, Philip Morris Research Laboratories GmbH, Cologne, Germany

${ }^{2}$ Philip Morris International R\&D, Philip Morris Products S.A., Neuchâtel, Switzerland

${ }^{3}$ Philip Morris International R\&D, Philip Morris Research Laboratories bvba, Leuven, Belgium

${ }^{4}$ Helix 3 Inc., Morrisville, NC, USA

${ }^{5}$ Institute of Anatomy, Medical Faculty, Technical University Dresden, Germany

\section{SUMMARY}

Oxidative stress is a basic mechanism involved in both ageand smoking-related diseases. To test whether smoking affects young, old, and calorie-restricted organisms to the same extent, we assessed oxidative stress parameters in the lung, heart, and liver of male Fischer 344 rats (4 months old and 19-22 months old) exposed to air or cigarette mainstream smoke. Smoke-related effects were seen for parameters of DNA damage, lipid peroxidation, protein oxidation, and glycoxidation. No smoke-related effects were observed for DNA damage in the lung and heart (Comet assay) and for malondialdehyde in the lung. The old rats showed higher smoke-related responses than the young rats for 8 -hydroxy-desoxyguanosine $(8-\mathrm{OHdG})$ in the heart and liver, DNA damage in the liver, and protein carbonyls in the lung; however, there was little evidence for an overadditive effect of smoking on aging. Caloric restriction, which is known to retard aging effects, also had little impact on smoke-related oxidative changes. [Beitr. Tabakforsch. Int. 26 (2014) 109-120]

\section{ZUSAMMENFASSUNG}

Oxidativer Stress ist ein Faktor, der sowohl in alters- als auch in zigarettenrauchbedingten Krankheiten eine wichtige Rolle spielt. Um nachzuprüfen, ob Zigarettenrauch den gleichen Einfluss auf junge, alte und kalorienreduzierte Organismen hat, bestimmten wir Parameter für oxidativen Stress in Lunge, Herz und Leber von männlichen Fischer 344 Ratten (Alter: 4 und 19-22 Monate), die Frischluft oder Hauptstromrauch von Zigaretten exponiert worden waren. Rauchbedingte Effekte wurden bei Parametern für DNASchäden, Lipidperoxidation, Proteinoxidation und Glykoxidation beobachtet. Keine rauchbedingten Effekte wurden im Comet Assay in Lunge und Herz und für die Malondialdehyd-Konzentration in der Lunge gefunden. Alte Ratten zeigten ausgeprägtere rauchbedingte Effekte als junge Ratten bezüglich 8-Hydroxy-desoxyguanosin (8-OHdG) in Herz und Leber, DNA-Schäden in der Leber und Proteinkarbonylen in der Lunge. Es gab jedoch keine Hinweise auf einen überadditiven Effekt bezüglich des Rauchens und Alterns. Gleichermaßen hatte eine Kalorienbegrenzung, von der bekannt ist, dass sie Alterseffekte verzögert, wenig Auswirkungen auf rauchbedingte oxidative Veränderungen. [Beitr. Tabakforsch. Int. 26 (2014) 109-120]

\section{RESUME}

Le stress oxydatif est un mécanisme fondamental, à l'œuvre tant dans les pathologies liées au tabagisme qu'à celles liées à l'âge. Dans le but de déterminer si le tabagisme affecte, dans une même mesure, les organismes jeunes, vieux et ceux soumis à un régime limité en calories, nous avons 
suivi les paramètres de stress oxydatif au niveau des poumons, du cœur et du foie de rats Fischer 344 de sexe mâle (individus âgés à 4 mois et individus âgés de 19 à 22 mois) exposés à l'air ou à une fumée principale de cigarette. Des effets liés au tabac ont été observés en suivant les paramètres tels que les lésions $\mathrm{ADN}$, la peroxydation lipidique, l'oxydation des protéines et la glycoxydation. Aucun effet lié au tabac n'a été observé en termes de lésions de l'ADN dans les poumons et le cœur (test des comètes) et de présence de malondialdéhyde dans les poumons. Les rats âgés ont présenté des réactions plus intenses liées au tabac que les rats plus jeunes en termes de présence de 8-hydroxy-déoxyguanosine (8-OHdG) dans le cœur et le foie, de lésions ADN au niveau du foie et de groupements carbonyles dans les protéines des poumons; néanmoins, peu de preuves ont été apportées d'un effet suradditif du tabagisme sur le vieillissement. Il s'est avéré également qu'un régime limité en calories, connu pour son effet de retardement du processus de vieillissement, n'exerçait qu'une faible incidence sur l'oxydation liée au tabagisme. [Beitr. Tabakforsch. Int. 26 (2014) 109-120]

\section{KEYWORDS}

Aging, cigarette smoke, oxidative stress, glycoxidative stress, Fischer 344 rat

\section{ABBREVIATIONS}

$\begin{array}{ll}\text { AGEs } & \text { advanced glycation end-products } \\ \text { ATP } & \text { adenosin triphosphate } \\ \text { CML } & \text { carboxymethyl-lysine } \\ \text { CR } & \text { caloric restriction } \\ \text { DMSO } & \text { dimethyl sulfoxide } \\ \text { DTT } & \text { dithiothreitol } \\ \text { HbCO } & \begin{array}{l}\text { carbon monoxide hemoglobin } \\ \text { (carboxyhemoglobin) }\end{array} \\ \text { HNE } & \text { 4-hydroxynonenal } \\ \text { MDA } & \text { malondialdehyde } \\ \text { 8-OHdG } & \text { 8-hydroxy-desoxyguanosine } \\ \text { PA } & \text { proteasome activity } \\ \text { PBS } & \text { phosphate buffered saline } \\ \text { PCO } & \text { protein carbonyl } \\ \text { RAGE } & \text { receptor for advanced glycation end-products } \\ \text { TPM } & \text { total particulate matter }\end{array}$

\section{INTRODUCTION}

The mechanisms underlying biological aging and the toxicological pathways activated by cigarette smoking are complex and far from fully understood. However, there are several similarities between aging and smoking with regard to their impact on the organism in terms of their final outcomes, i.e., degenerative diseases and increased risk of mortality $(1,2)$. Two of the basic mechanisms contributing to degenerative diseases and aging, as well as to the effects of smoking, are oxidative stress and glycoxidative stress. Oxidative stress plays an important role in the age-related gradual and progressive loss of physiological function and homeostasis $(3,4)$. The "oxidative stress theory" $(5,6)$ states that reactive oxidants generated by the environment or by cellular metabolism increasingly disturb biochemical cellular functions and damage cellular components such as lipids, proteins, and nucleic acids. However, there are also views that question the direction of this causal relationship and postulate that an increased production of reactive oxygen species is simply a manifestation of the cellular disturbances $(7,8)$.

The major sources of intrinsic reactive oxidants originate from the cellular metabolism itself and, in particular, from the mitochondria (9-11), but other sources of oxidants, such as deposits of lipofuscin in the lysosomes, have also been described in aged cells (12). Conversely, caloric restriction (CR) is known to retard biological aging (13), most likely by reducing endogenous oxidant production (14).

Cigarette smoke contains a large amount of free radicals $(15,16)$ and compounds interacting specifically with the DNA (17), leading to the known mutagenic and carcinogenic activity of cigarette smoke in humans and experimental systems (18-21). Tobacco and cigarette smoke also contain Maillard reaction products, which result from the reaction of tobacco proteins with tobacco sugars. Similar proteinsugar reactions also occur naturally within the organism, where they can cascade in additional radical stress, resulting in advanced glycation end-products (AGEs). Exogenously absorbed AGEs by nutrition or by cigarette smoke, as a lifestyle factor, pass the receptor for AGEs (RAGE), which is known to induce additional inflammation processes (22). The complex AGE reactions that lead to glycoxidative stress are involved in the occurrence of several degenerative diseases. Increased levels of AGEs have been found in smokers (23) and AGEs have also been reported to be involved in aging (24).

Because aging is connected with an increased oxidative load, and smoke exposure is an additional source of oxidants, we expected that oxidative stress parameters would be more expressed in old rats than in young rats and more in smoke-exposed rats than in unexposed rats. Of special interest was the question of whether there is an interaction between smoking and aging. We therefore measured a set of established toxicological parameters characterizing oxidative and glycoxidative exposure in the lung and other organs in young and old Fischer 344 rats, either unexposed or exposed to cigarette smoke:

- 8-Hydroxy-deoxyguanosine, as one of the major elimination products of DNA oxidation.

- Comet assay, as a tool to detect general DNA damage such as strand breaks.

- 4-Hydroxynonenal and malondialdehyde, as products of lipid peroxidation.

- Malondialdehyde: a product of oxidative degradation of polyunsaturated lipids.

- Protein carbonyls, as products of protein oxidation.

- Proteasome activity, the activity of an enzyme that degrades damaged proteins, like protein carbonyls by proteolysis.

- Carboxymethyl-lysine, one of the major advanced glycation end-products formed on proteins by combined nonenzymatic glycation and oxidation.

- Glutathione, an endogenous antioxidant. 


\section{MATERIAL AND METHODS}

\section{Animals and smoke exposure}

Young (4 months) and old (19-22 months) male Fischer 344 rats were obtained from the National Institute of Aging, Bethesda, MD, USA. The rats were kept under controlled conditions and allowed to adapt to their new environment for 10 days at Philip Morris Research Laboratories bvba in Leuven, Belgium, an Association for Assessment and Accreditation of Laboratory Animal Care (AAALAC)-approved laboratory (25). The rats (10 per group) were fed ad libitum and exposed nose-only in restrainer tubes to diluted mainstream smoke from the Reference Cigarette 2R4F (26) or to conditioned fresh air 3 times per day for $60 \mathrm{~min}$ (with 30-min intervals between exposures), 7 days/week, for 35-39 days. Two additional caloric restriction groups of old rats were continued on a calorie-restricted diet, i.e., NIH-31/NIA-fortified diet (National Institute of Aging formula, obtained from Harlan Laboratories, Rossdorf, Germany) with $60 \%$ of normal energy intake, and exposed to smoke or fresh air for 35 days. All animal exposure experiments were approved by the Institutional Animal Care and Use Committee.

Cigarettes were smoked on automatic smoking machines according to ISO standards (27). The smoke was mixed with filtered fresh air to a final concentration of $450 \mu \mathrm{g}$ total particular matter (TPM)/L, which corresponds to a nicotine concentration of between 36 and $39 \mu \mathrm{g} / \mathrm{L}$. More details on smoke generation and exposure conditions are described elsewhere (28).

Animals were weighed before dissection and euthanized under pentobarbital anesthesia. Smoke exposed animals got a 1-hour exposure on the dissection day. Time between last exposure and dissection was between $30 \mathrm{~min}$ and 2 hours. The abdominal cavity was opened and blood was removed immediately. Organs were removed and tissues were separated according to the stereological distribution technique (29). Samples were then either analyzed directly or snap frozen in liquid nitrogen and stored at $-80^{\circ} \mathrm{C}$ until analysis. Prior to measurements, frozen tissues were homogenized in PBS and stored on ice. Clinical-chemistry and biological parameters were determined for quality control (results not shown).

\section{8-Hydroxy-deoxyguanosine}

8-Hydroxy-deoxyguanosine (8-OHdG) was determined according to BADER et al. (30). DNA was extracted using the Blood and Cell Culture DNA Kit (Qiagen, Hilden, Germany). The heat-denatured DNA was treated with $40 \mathrm{U}$ exonuclease $\mathrm{I}$ and $4 \mathrm{U}$ alkaline phosphatase for $1 \mathrm{~h}$ at $37{ }^{\circ} \mathrm{C}$. The resulting solution was centrifuged and filtered through a $30 \mathrm{kDa}$ filter (Millipore, Veverly, MA, USA). The nucleosides were separated on a Beckmann-Coulter HPLC system using a diode array and electrochemical detection modus. A reversed-phase Protosil 120-5-C18 AQ column $(250 \times 3 \mathrm{~mm}, 5 \mu \mathrm{m}$, Bischoff, Leonberg, Germany) was used. Isocratic analysis was performed at a flow rate of $0.5 \mathrm{~mL} / \mathrm{min}$ using $50 \mathrm{mM}$ citrate, $2 \mathrm{mM} \mathrm{KCl}, 15 \mu \mathrm{M}$ EDTA, and $11.5 \%$ methanol as eluent.

\section{Comet assay (single cell gel electrophoresis)}

Fresh tissue samples were minced in ice-cold Hanks' Balanced Salt Solution $\left(\mathrm{Mg}^{2+}\right.$ and $\mathrm{Ca}^{2+}$ free $)$, mixed with a low melting agarose at $37^{\circ} \mathrm{C}$, and placed on a glass slide. After topping the cell suspension with another layer of low melting point agarose, the cells were lyzed overnight and the DNA was electrophoretically separated at $0.7 \mathrm{~V} / \mathrm{cm}$ and $300 \mathrm{~mA}$ in alkaline buffer $\mathrm{pH}>13$ under ambient conditions. After electrophoresis, the DNA was stained with SYBR Gold ${ }^{\mathrm{TM}}$ and 50 cells per slide ( 2 slides per sample) were analyzed using the Komet $^{\odot}$ GLP Image Analysis System Version 6.0.2.3 (Kinetic Imaging Ltd., Nottingham, UK). For the CR groups, staining was done with ethidium bromide (leading to significantly higher measurement readings). The tail moment, defined as the distance between DNA in the 'head' and main DNA concentration in the 'tail' multiplied by the amount of DNA in the 'tail', was used as the parameter for general DNA damage (31).

\section{4-Hydroxynonenal}

4-Hydroxynonenal (HNE) was determined according to GIL et al. (32). $2.5 \mathrm{~mL}$ of tissue homogenate was incubated for $2 \mathrm{~h}$ in the dark with $2.5 \mathrm{~mL}$ of dinitrophenylhydrazine solution $(1.8 \mathrm{mM}$ in $1 \mathrm{M} \mathrm{HCl})$ at room temperature. The organic phase was extracted with dichloromethane before evaporating it to dryness. The residue was re-dissolved with $1.5 \mathrm{~mL}$ of dichloromethane and spotted on thin layer chromatography plates, which were developed with dichloromethane. The zone containing the 4-hydroxyalkenals was scraped off, extracted with methanol, and evaporated to dryness. The residue was dissolved in $1 \mathrm{~mL}$ of methanol. Methanol/water $(4: 1, v: v)$ was used as eluent for the isocratic HPLC analysis.

\section{Malondialdehyde}

Malondialdehyde (MDA) was determined according to GIL et al. (32). Tissue samples were boiled in the presence of thiobarbituric acid for $60 \mathrm{~min}$; the reaction was stopped by cooling the samples in an ice bath. After neutralization the samples were analyzed by HPLC using a $150 \mathrm{~mm}$ LC-18-S (5 mM) Supelcosil reversed-phase column (Supelco, Deisenhofen, Germany) and isocratic potassium phosphate buffer/methanol as eluent.

\section{Protein carbonyls}

Protein carbonyl (PCO) content was determined in the homogenized tissue supernatant with protein concentrations of $2 \mathrm{mg} / \mathrm{mL}$, employing a modified ELISA method (33, 34). An anti-dinitrophenyl rabbit IgG-antiserum (Sigma, Deisenhofen, Germany) was used as the primary antibody and a monoclonal anti-rabbit IgG antibody peroxidase conjugate (Sigma) as the secondary antibody. Development was performed with $o$-phenylenediamine and $\mathrm{H}_{2} \mathrm{O}_{2}$.

\section{Proteasome activity}

For specific determination of the ATP-independent (20S) proteasome activity (PA), cell lysates were adjusted to $1 \mathrm{mg}$ 
Table 1. Biomarkers of oxidative stress in old and young rats exposed to air or cigarette mainstream smoke. Units are shown in brackets, $\mathrm{AU}=$ arbitrary unit.

\begin{tabular}{|c|c|c|c|c|c|c|c|c|c|c|c|c|c|}
\hline \multirow{5}{*}{ Biomarker } & \multirow{5}{*}{ Organ } & \multicolumn{12}{|c|}{ Group } \\
\hline & & \multicolumn{8}{|c|}{ Ad libitum } & \multirow{2}{*}{\multicolumn{4}{|c|}{$\begin{array}{c}\text { Caloric restrictions } \\
\text { Old rats }\end{array}$}} \\
\hline & & \multicolumn{4}{|c|}{ Young rats } & \multicolumn{4}{|c|}{ Old rats } & & & & \\
\hline & & \multicolumn{2}{|c|}{ Air } & \multicolumn{2}{|c|}{ Smoke } & \multicolumn{2}{|c|}{ Air } & \multicolumn{2}{|c|}{ Smoke } & \multicolumn{2}{|c|}{ Air } & \multicolumn{2}{|c|}{ Smoke } \\
\hline & & Mean & SE & Mean & SE & Mean & SE & Mean & SE & Mean & SE & Mean & SE \\
\hline \multirow{3}{*}{$\begin{array}{l}\text { 8-OHdG } \\
\text { (8-OHdG/1E5 dG) }\end{array}$} & lung & 3.69 & 0.30 & 5.62 & 0.29 & 4.64 & 0.31 & 5.26 & 0.47 & 4.68 & 0.97 & 7.08 & 1.21 \\
\hline & heart & 4.46 & 0.53 & 6.19 & 0.45 & 5.76 & 0.35 & 10.92 & 1.16 & 6.03 & 0.28 & 5.74 & 0.89 \\
\hline & liver & 3.78 & 0.24 & 1.58 & 0.18 & 1.96 & 0.33 & 3.54 & 0.58 & 3.68 & 0.32 & 5.88 & 1.15 \\
\hline \multirow{3}{*}{$\begin{array}{l}\text { Comet } \\
\text { (tail moment) }\end{array}$} & lung & 11.2 & 0.8 & 11.2 & 1.0 & 10.8 & 1.0 & 10.2 & 0.7 & 47.7 & 4.9 & 69.4 & 6.9 \\
\hline & heart & 17.3 & 1.1 & 17.7 & 1.1 & 19.0 & 1.1 & 20.0 & 1.8 & 79.0 & 7.0 & 89.7 & 7.0 \\
\hline & liver & 6.3 & 0.6 & 8.7 & 0.9 & 7.3 & 0.7 & 11.4 & 1.7 & 33.2 & 4.1 & 36.3 & 3.2 \\
\hline 4-HNE (pmol/mg) & lung & 0.106 & 0.025 & 0.140 & 0.062 & 0.081 & 0.019 & 0.030 & 0.014 & 0.141 & 0.058 & 0.116 & 0.038 \\
\hline MDA (nmol/mg) & lung & 0.300 & 0.032 & 0.221 & 0.019 & 0.203 & 0.014 & 0.219 & 0.020 & 0.096 & 0.006 & 0.140 & 0.007 \\
\hline $\mathrm{PCO}(\mathrm{nmol} / \mathrm{mg})$ & lung & 0.586 & 0.098 & 0.333 & 0.058 & 0.288 & 0.077 & 0.944 & 0.298 & 0.553 & 0.035 & 0.425 & 0.084 \\
\hline $\mathrm{PA}$ (nmol/mg/min) & lung & 0.0299 & 0.0007 & 0.0333 & 0.0006 & 0.0290 & 0.0006 & 0.0306 & 0.0007 & 0.0290 & 0.0006 & 0.0287 & 0.0007 \\
\hline $\mathrm{GSH}(\mu \mathrm{mol} / \mathrm{L})$ & lung & 28.8 & 1.9 & 21.9 & 1.7 & 32.7 & 2.1 & 27.3 & 1.7 & 13.5 & 4.2 & 17.5 & 4.0 \\
\hline \multirow[t]{2}{*}{ CML (AU) } & $\begin{array}{l}\text { lung, } \\
\text { macrophages }\end{array}$ & 3.28 & 0.23 & 4.54 & 0.10 & 3.90 & 0.10 & 4.36 & 0.09 & 3.58 & 0.20 & 4.40 & 0.12 \\
\hline & $\begin{array}{l}\text { alveolar } \\
\text { epithelium }\end{array}$ & 2.90 & 0.28 & 4.36 & 0.07 & 3.38 & 0.17 & 3.97 & 0.16 & 3.70 & 0.23 & 3.90 & 0.12 \\
\hline
\end{tabular}

protein $/ \mathrm{mL}$, and $10 \mu \mathrm{l}$ of the lyzed cells in $33.3 \mu \mathrm{l}$ of 3 fold-concentrated incubation buffer was transferred into each well of a 96-well microtiter plate. The fluorogenic peptide suc-LLVY-MCA (Enzo Life Sciences, Plymouth Meeting, PA, USA) was added at a final concentration of $0.2 \mathrm{mM}$ (stock solution $2 \mathrm{mM}$ in DMSO). The mixture was incubated for $30 \mathrm{~min}$ at $37^{\circ} \mathrm{C}$. The amount of the cleaved peptide releasing fluorescent MCA is directly proportional to the proteasomal activity. Fluorescence was determined in a fluorometer at an excitation wavelength of $390 \mathrm{~nm}$ and an emission wavelength of $460 \mathrm{~nm}$. Free MCA was used as standard. The proteasome-incubation buffer comprised

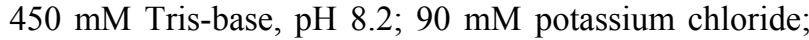
$15 \mathrm{mM} \mathrm{Mg}$-acetate; and $3 \mathrm{mM}$ DTT. The reagents were dissolved in water and stored at $-20{ }^{\circ} \mathrm{C}$. The reduction agent DTT was added freshly each day.

\section{Glutathione}

Total glutathione was determined by measuring reduced glutathione (GSH) and oxidized glutathione (GSSG) using the Glutathione Assay Kit 703002 (Cayman, Tallinn, Estonia). Basically, the plasma was treated with 5,5dithiobis-(2-nitrobenzoic acid) (DTNB). GSH reacts directly with DTNB, whereas GSSG is reduced by the added glutathione reductase. GSH-TNB derivative was determined at $405 \mathrm{~nm}$.

\section{Carboxymethyl-lysine}

For immunohistochemical carboxymethyl-lysine (CML) determination, formalin-fixed paraffin-embedded lung samples were cut and slides were treated with xylol replacement medium XEM-200 (limonene). The samples were boiled and endogen peroxidase activity was blocked by pretreatment with $1 \%$ hydrogen peroxide (35). After washing with PBS, the unspecific reactions of the primary antibody were blocked using goat serum. An anti-CML-rabbitantibody (gift of Prof. Schleicher, Tübingen, Germany) was used in a 1:2000 dilution. Incubation was performed for $1 \mathrm{~h}$ at $37{ }^{\circ} \mathrm{C}$. After washing, cells were incubated at room temperature for $45 \mathrm{~min}$ with the biotinylated secondary antibody (anti-rabbit-IgG; Vectastain, Vector Laboratories, Burlingame, CA, USA) in a 1:200 dilution. The Vectastain Elite ABC Peroxidase kit was used for development. Evaluation was done microscopically.

\section{Statistics}

All values reported are mean \pm standard error $(\mathrm{SE})$. Groups were compared by Student's t-test after exclusion of outliers identified by the Nalimov test. A p-value of $<0.05$ without corrections for multiple testing was considered statistically significant.

\section{RESULTS}

Table 1 gives an overview of the results obtained

As expected from the literature $(3,36,37)$, we found agerelated increases in oxidation parameters in our animal model, although the results were not always pronounced. As the lung is the first organ exposed to smoke, we tested oxidative stress parameters in the lung. With regard to 
Table 2. Differences by aging of old relative to young air-exposed rats and by smoke-exposure of smoke-exposed relative to air-exposed young, old, and old CR rats. Units are shown in brackets, $A U$ = arbitrary unit.

\begin{tabular}{|c|c|c|c|c|c|c|c|c|c|c|c|c|c|}
\hline \multirow{3}{*}{ Biomarker } & \multirow{3}{*}{ Organ } & \multirow{2}{*}{\multicolumn{3}{|c|}{$\begin{array}{c}\text { Aging } \\
\text { old relative to young } \\
\text { Air-exposed }\end{array}$}} & \multicolumn{9}{|c|}{$\begin{array}{c}\text { Smoking } \\
\text { smoke-exposed relative to air-exposed }\end{array}$} \\
\hline & & & & & \multicolumn{3}{|c|}{ Young } & \multicolumn{3}{|c|}{ Old } & \multicolumn{3}{|c|}{ Old caloric restriction } \\
\hline & & $\mathrm{M} / \mathrm{M}$ & $p$ & $\mathrm{~N}$ & $\mathrm{M} / \mathrm{M}$ & $p$ & $\mathrm{~N}$ & $\mathrm{M} / \mathrm{M}$ & $p$ & $\mathrm{~N}$ & $\mathrm{M} / \mathrm{M}$ & $p$ & $\mathrm{~N}$ \\
\hline \multirow{3}{*}{$\begin{array}{l}\text { 8-OhdG } \\
\text { (8-OhdG/1E5 dG) }\end{array}$} & lung & 1,26 & 0,042 * & $9 / 10$ & 1,52 & $0,0008^{* \star *}$ & $6 / 10$ & 1,13 & 0,2923 & $9 / 9$ & 1,51 & 0,1359 & $9 / 10$ \\
\hline & heart & 1,29 & 0,0643 & $8 / 9$ & 1,39 & 0,0318 * & $7 / 9$ & 1,90 & $0,0006 * * *$ & $7 / 8$ & 0,95 & 0,7533 & $9 / 10$ \\
\hline & liver & 0,52 & $0,0004^{* * *}$ & $8 / 9$ & 0,42 & $0,0000 * * *$ & $6 / 9$ & 1,81 & 0,0323 * & $8 / 8$ & 1,60 & 0,0834 & $10 / 10$ \\
\hline \multirow{3}{*}{$\begin{array}{l}\text { Comet } \\
\text { (Tail moment) }\end{array}$} & lung & 0,96 & 0,7429 & $10 / 9$ & 1,00 & 0,9753 & $6 / 9$ & 0,95 & 0,6600 & $9 / 10$ & 1,45 & 0,0185 * & $8 / 10$ \\
\hline & heart & 1,10 & 0,2871 & $9 / 10$ & 1,02 & 0,8174 & $7 / 10$ & 1,05 & 0,6456 & $9 / 9$ & 1,14 & 0,3010 & $8 / 10$ \\
\hline & liver & 1,16 & 0,2911 & $9 / 9$ & 1,37 & 0,0342 * & $7 / 9$ & 1,56 & 0,0460 * & $9 / 9$ & 1,09 & 0,5731 & $8 / 10$ \\
\hline 4-HNE (pmol/mg) & lung & 0,77 & 0,4720 & $7 / 9$ & 1,32 & 0,5545 & $5 / 9$ & 0,36 & 0,0531 & $6 / 7$ & 0,82 & 0,7082 & $10 / 6$ \\
\hline MDA (mmol/mg) & lung & 0,68 & 0,0128 * & $9 / 9$ & 0,74 & 0,0660 & $7 / 9$ & 1,08 & 0,5108 & $9 / 9$ & 1,45 & 0,0002 *** & $9 / 10$ \\
\hline $\mathrm{PCO}(\mathrm{mmol} / \mathrm{mg})$ & lung & 0,49 & 0,0291 * & $9 / 9$ & 0,57 & 0,0582 & $7 / 9$ & 3,28 & 0,0490 * & $9 / 9$ & 0,77 & 0,1513 & $9 / 11$ \\
\hline $\mathrm{PA}(\mathrm{mmol} / \mathrm{mg} / \mathrm{min})$ & lung & 0,97 & 0,3612 & $9 / 10$ & 1,11 & 0,0058 ** & $6 / 10$ & 1,05 & 0,1107 & $8 / 9$ & 0,99 & 0,7685 & $9 / 10$ \\
\hline $\mathrm{GSH}(\mu \mathrm{mol} / \mathrm{L})$ & serum & 1,13 & 0,1896 & $8 / 8$ & 0,76 & 0,0213 * & $6 / 8$ & 0,84 & 0,0658 & $9 / 8$ & 1,30 & 0,5125 & $6 / 4$ \\
\hline \multirow[t]{2}{*}{ CML (AU) } & $\begin{array}{l}\text { lung, } \\
\text { macrophages }\end{array}$ & 1,19 & 0,0206 * & $10 / 10$ & 1,38 & 0,0005 & $7 / 10$ & 1,12 & 0,0039 & $9 / 10$ & 1,23 & 0,0024 & $10 / 10$ \\
\hline & $\begin{array}{l}\text { alveolar } \\
\text { epithelium }\end{array}$ & 1,16 & 0,1621 & $10 / 10$ & 1,50 & 0,0007 & $7 / 10$ & 1,18 & 0,0197 & $9 / 10$ & 1,05 & 0,4486 & $10 / 10$ \\
\hline
\end{tabular}

Statistics:

Values of each group (except for $\mathrm{CML}$ ) were tested for outliers according to Nalimov at $\mathrm{p} \leq 0.05$.

Comparison between groups: t-test; M: arithmetic mean; p: probability; N: number of rats per exposure group; *: statistically significant at $p \leq 0.05 ;{ }^{* *}: p \leq 0.01 ;{ }^{* * *}: p \leq 0.001$.

DNA damage, an age-related increase in the amount of 8$\mathrm{OHdG}$ in lung tissue was found in the air-exposed rats, and a smoke-related increase was found in young and old rats. A smoke effect was also seen in old rats but it was rather weak and did not reach statistical significance (Table 2, Fig. 1). To test whether this holds true for other organs, we also measured 8-OHdG in the heart and liver. In the heart, age-related increases were indicated in air-exposed rats, and smoke-related increases were seen in both young and old rats, with a very strong increase in old rats (Table 2 , Fig. 1). In the liver, there was an age-related decrease and a smoke-related decrease seen in young rats, but a strong smoke-related increase in old rats.

Because $8-\mathrm{OHdG}$ is the elimination product of oxidatively damaged DNA, direct measurement of general DNA damage, e.g., DNA strand breaks, should show similar smokerelated features in both age groups. To demonstrate this, we measured DNA damage in the Comet assay, however, neither age- nor smoke-related increases were seen in the lung. Ageand smoke-related increases were indicated in the heart and clearly visible in the liver. In the liver, they were again higher in old rats than in young rats (Table 2, Fig. 2). To further elucidate the age- and smoke-related effects of oxidative stress in the lung, we measured HNE, PCOs, and MDA. An age-related decrease was seen for MDA and PCOs and a smoke-related decrease (not statistically significant) was seen in young rats; while a strong increase was seen in old smokeexposed rats for PCOs (Table 2, Fig. 3). An age-related
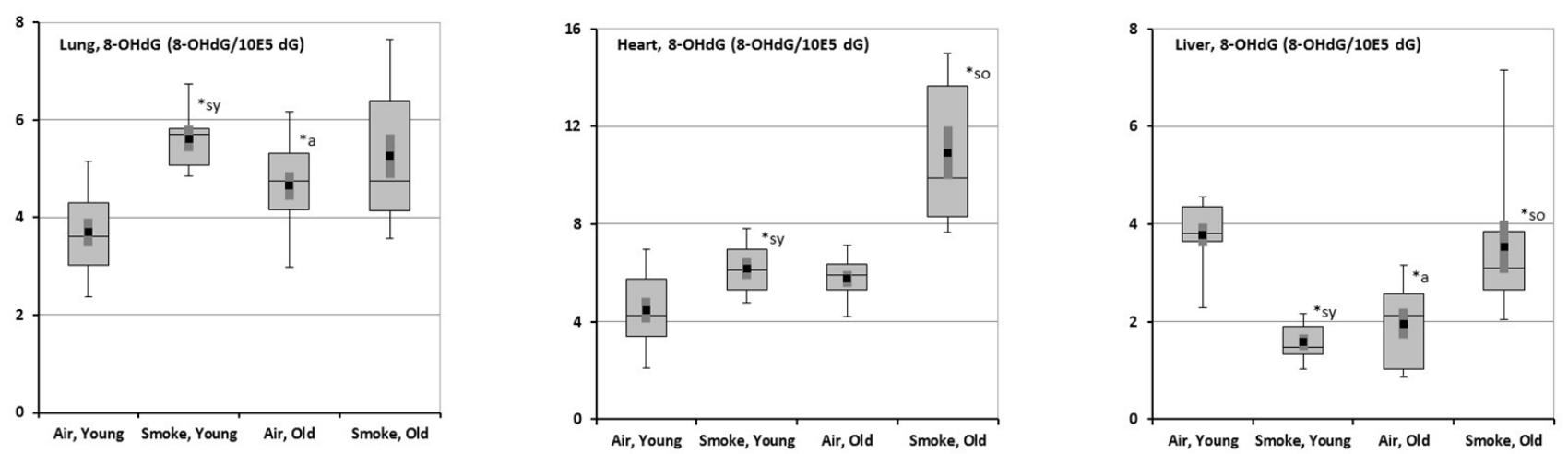

Figure 1. Effects of cigarette smoke exposure on the 8-OHdG content in young and old rats. Young rats (4 months old) and old rats ( 20 months old) were exposed to fresh air or to cigarette smoke (450 $\mu \mathrm{g}$ TPM/L) for 39 days. Data represent mean \pm SE. Statistically significant differences: *a: old compared to young rats, *sy: smoke-exposed compared to air-exposed young rats, *so: smoke-exposed compared to air-exposed old rats (for details see Table 2). 

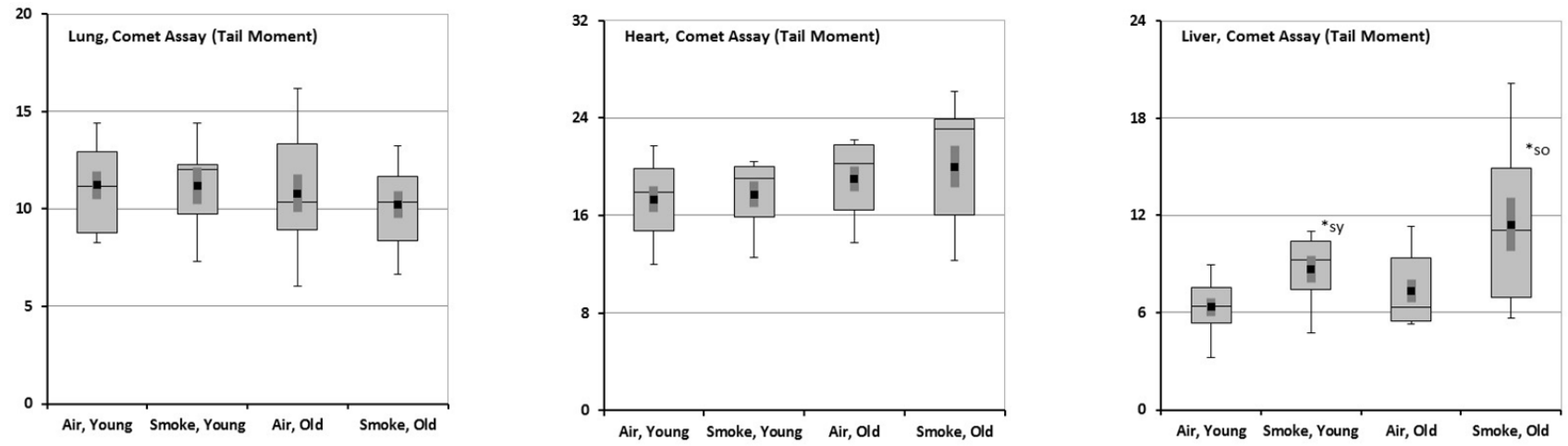

Figure 2. Effects of cigarette smoke exposure on the DNA damage in young and old rats as measured by the Comet assay.
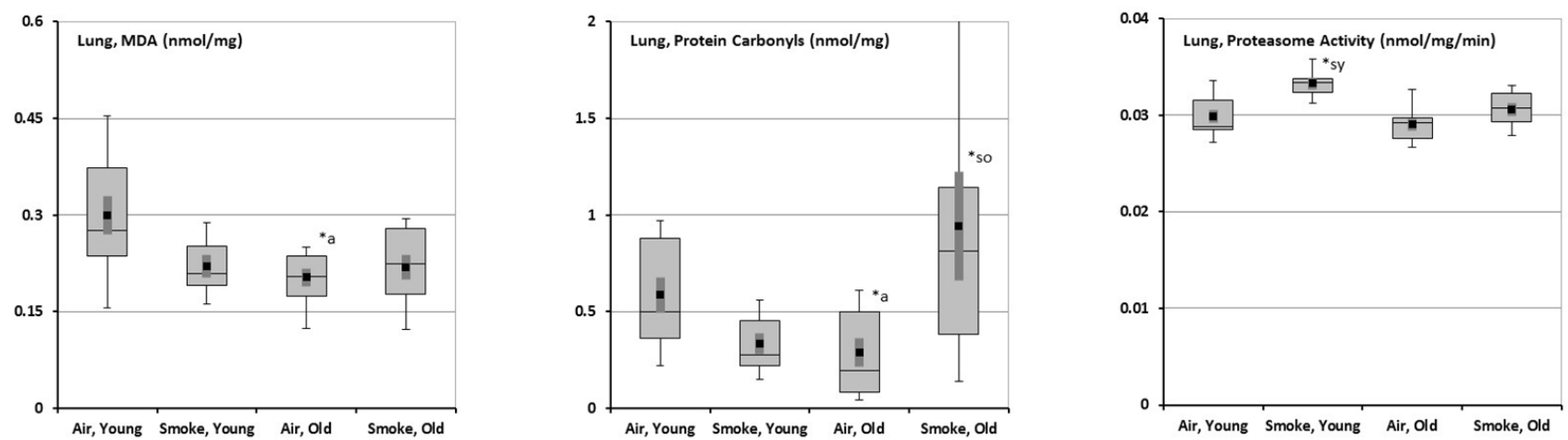

Figure 3. Effects of cigarette smoke exposure on malondialdehyde, protein carbonyls, and proteasome activity in the lungs of young and old rats.

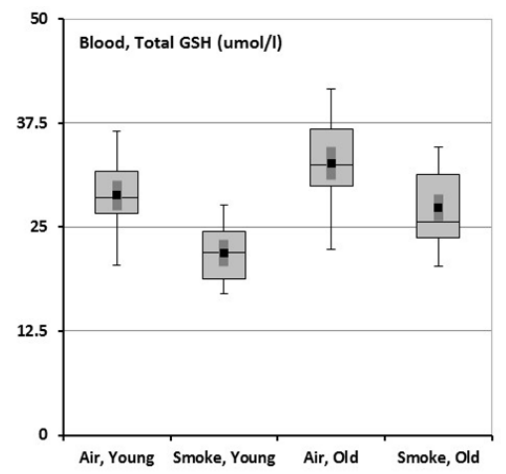

Figure 4. Effects of cigarette smoke exposure on total glutathione in plasma of young and old rats.
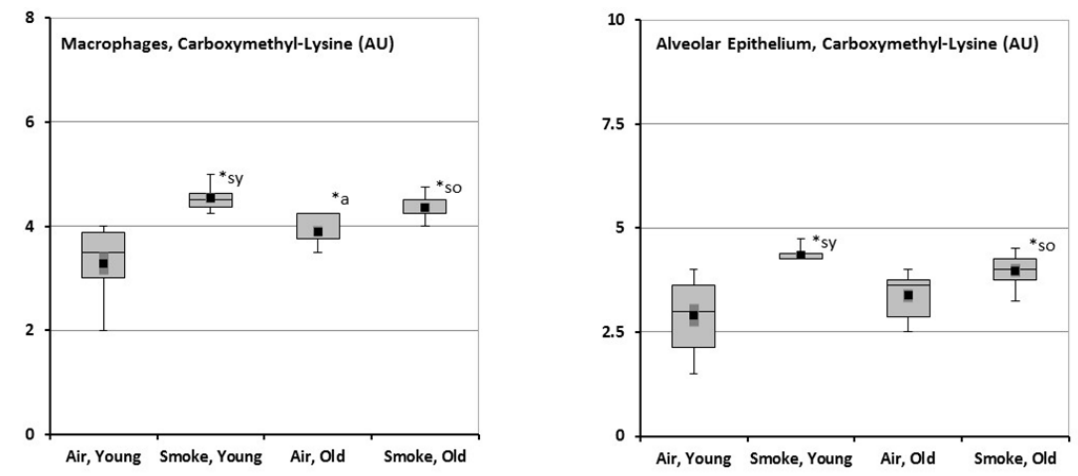

Figure 5. Effects of cigarette smoke exposure on carboxymethyl-lysine in the lungs of young and old rats.

Figures 2-5: Young rats (4 months old) and old rats ( 20 months old) were exposed to fresh air or to cigarette smoke (450 $\mu \mathrm{g}$ TPM/L) for 39 days. Data represent mean \pm SE. Statistically significant differences: *a: old compared to young rats, ${ }^{*}$ sy: smoke-exposed compared to air-exposed young rats, *so: smoke-exposed compared to air-exposed old rats (for details see Table 2).

inverse correlation between the PCO content and the 20S proteasome activity has been reported in the lung (38). The expected age-related decrease was observed in smokeexposed rats but only indicated in unexposed rats. The smoke exposure itself minimally $(10 \%)$ increased proteasome activity in young but not in old rats (Table 2, Fig. 3).

Because some of the oxidative stress parameters failed to demonstrate the expected increase, we investigated the antioxidative protective capacity as reflected by the total glutathione content. Whereas aging per se was not accom- panied by a decline in the glutathione amount in our model but rather by a slight increase, cigarette smoke exposure did lead to a decline of this antioxidative defense capacity in both young and old rats (Table 2, Fig. 4).

To investigate the influence of advanced glycation endproducts, we conducted a histochemical investigation of the lung. Age-related increases in air-exposed rats, as well as consistent smoke-related increases in young and old rats, were seen in the alveolar epithelium and lung macrophages for CML (Table 2, Fig. 5). 

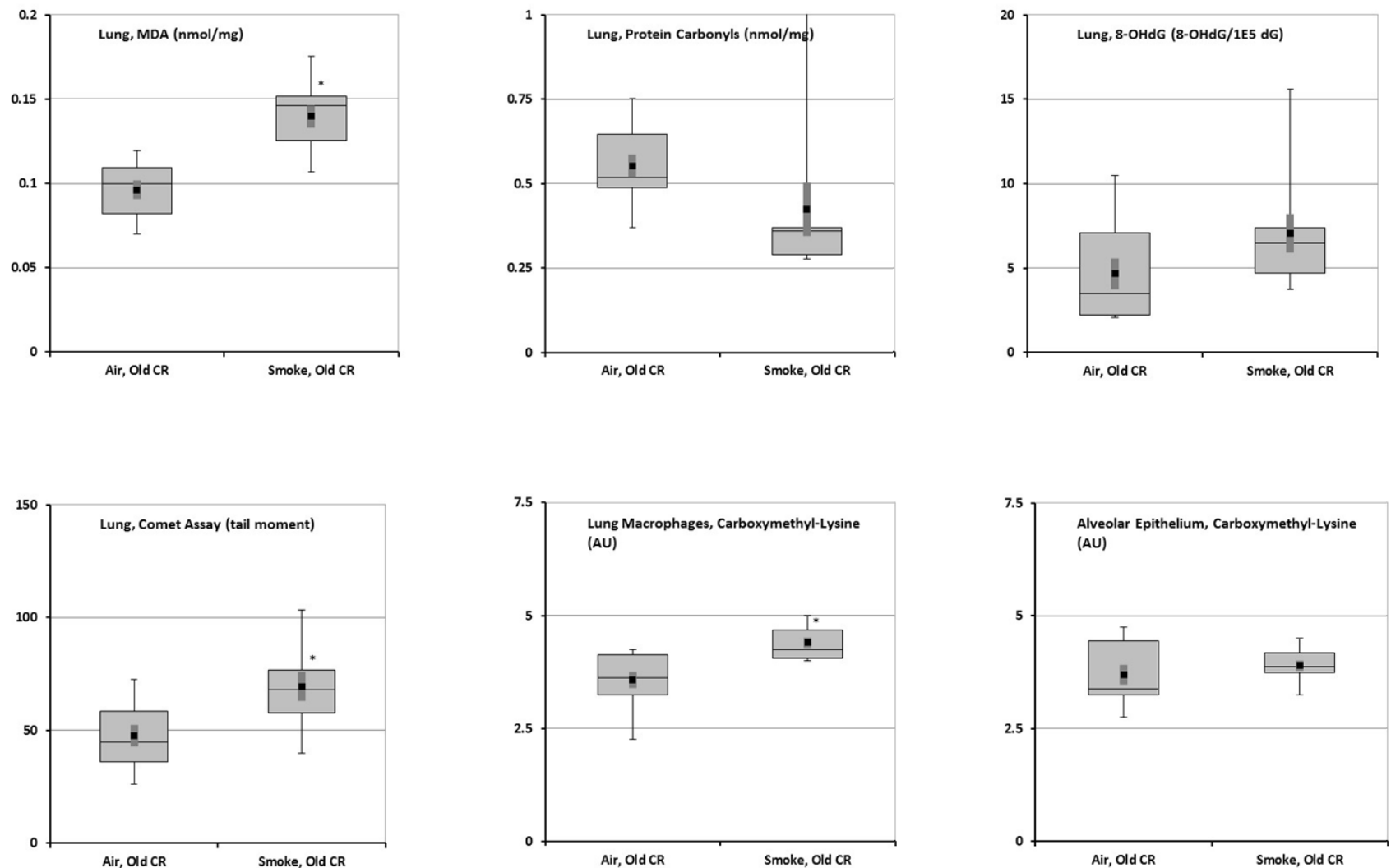

Figure 6. Effects of cigarette smoke exposure on oxidative and glycoxidative stress parameters in the lungs of calorie-restricted rats. Old calorie-restricted rats ( 20 months old) were exposed to fresh air or to cigarette smoke (450 $\mu \mathrm{g}$ TPM/L) for 35 days. Data represent mean \pm SE. Statistically significant differences: *a: old compared to young rats, *s: air-exposed compared to smoke-exposed rats (for details see Table 2).

Because caloric restriction has been reported to counteract age-related changes in metabolism and the related oxidant production (39), we also investigated the effects of cigarette smoke in the lungs of old, calorie-restricted rats. Smokerelated increases were seen for DNA-damaging effects, as measured by $8-\mathrm{OHdG}$ and Comet assay; for lipid peroxidation, as measured by MDA; and for the glycoxidative stress parameter CML in lung macrophages; while a decrease was indicated for protein oxidation, as measured by PCO levels. Interestingly, $\mathrm{PCO}$ and MDA levels in lung and 8-OHdG in heart of smoke-exposed old rats were reduced by approximately $50 \%$ (Table 2, Fig. 6).

\section{DISCUSSION}

Many of the degenerative diseases and cancers that are associated with aging are seen in both smokers and nonsmokers. However, the onset of these diseases generally occurs at an earlier stage of life in smokers than in nonsmokers (40-45). The similarities between smoking and aging have been discussed in the literature (46), but have not yet been comprehensively experimentally investigated. With the present work, we aimed to investigate the combined influences of smoke exposure and the complex phenomenon of biological aging.

In order to differentiate between aging and smoking, we needed to first analyze the age-related effects. The agerelated increases seen in air-exposed rats, i.e., $8-\mathrm{OHdG}$ in the lung and CML in lung macrophages, support the role of oxidative and glycoxidative stress in aging, while the decreases, i.e., 8-OHdG in the liver and MDA and PCOs in the lung, cannot be explained by oxidative stress. These results might possibly be explained better by the theory that age-related changes induced by oxidative stress may be balanced to a certain degree by an organism's intrinsic defense metabolism $(47,48)$. No age-related changes were seen for the other parameters in this model, which appears to contradict the theory that oxidative stress induces aging directly. However, there is an abundance of contradictory results in the literature for the same parameter in the same tissue from different laboratories, which may be explained by differences in species, strain, sex, and age of the rats investigated (49-55). Moreover, such inconsistencies have been reported from the same laboratories either with the same parameter in different tissues (56-58) or with different parameters related to oxidative stress in the same tissue (59-62). One important supporting finding was published by JANA et al. (63), who found species-specific differences in the age-dependent carbonylation of different proteins from different tissues within an organ and concluded that age-dependent carbonylation is a highly selective phenomenon rather than a randomized process, such as those generally associated with aging. It cannot be excluded that such specification may also be true for the other parameters. We randomized the organ tissue using the technique proposed by NYENGAARD (29), which does not allow differentiation between different tissues within an organ, 
because we wanted to ensure that we obtained a general result for each organ as a whole, and because it is not known which tissues within an organ respond to aging and oxidative stress. However, we cannot exclude the possibility that the sensitivity of these toxicological parameters is not sufficient to consistently show an overall age-related increase in damage, which may be more subtle than a toxic insult.

We analyzed smoke-related effects in young rats, which were 6 months old and sexually mature. This is different from the majority of smoke-related investigations, which generally use much younger rats, i.e., 8- to 10-week-old rats as suggested in OECD guidelines (64) and generally practiced in tobacco product testing (28). We chose to use 6-month-old rats to minimize the likelihood of interference from maturation processes. The smoke-related increase seen in the lung and heart (8-OHdG) and liver (Comet assay) support the role of oxidative stress in smoking, while the increase in CML in lung macrophages and alveolar epithelium supports the role of glycoxidative stress in smoking. Proteasome activity in the lung indicates increased elimination of damaged proteins.

The subchronic exposure regimen was chosen for this experiment to limit the possibility that the organism may adapt to the smoke (65); therefore, we expected to see a smoke effect on all of the oxidative stress parameters investigated. The decrease seen in glutathione in plasma indicates that the oxidative stress associated with smoke inhalation leads to an increased consumption of this antioxidant. However, the remaining antioxidative capacity might still represent an effective defense system, which may have counteracted effects in the other oxidative stress parameters. Depletion of glutathione by cigarette smoke has been described (66). The decrease in $8-\mathrm{OHdG}$ in the liver may be due to the detoxification of cigarette smoke toxins by the xenobiotic metabolism (67) and the higher elimination of $8-\mathrm{OHdG}$ due to nuclease activity (68). Again, different results to literature may be due, to some extent, to differences in sex, age, and species of the models investigated, however, they may also be due to differences in the smoke exposure conditions.

Analyzing the biomarkers in terms of the combined influence of smoke exposure and biological aging, which has not been investigated in this model before, revealed no clear pattern of effects. In fact, effects were not always more pronounced in old rats. This underlines the complexity of both the mechanisms of aging and the toxicity of cigarette smoke. With regard to DNA damage, the increases seen in older rats in the heart $(8-\mathrm{OHdG})$ and the liver (8-OHdG and Comet assay) suggest that the older rats are more susceptible to the cigarette smoke toxins that reach the circulatory system. No increase in DNA strand breaks was seen with the Comet assay in the lung, even though 8OHdG showed both an age-related increase and a smokerelated increase. However, the time between last exposure and dissection might have been too long. It has been reported, although under rather different smoke exposure conditions (1-min exposure and extremely high smoke concentration), that the level of DNA strand breaks in the lung returns to control values already after 1 hour (69). In vitro, cigarette smoke is clearly active (70). In peripheral lymphocytes of smoke-exposed rats the assay shows, at best, a weak response (71). The failure of the Comet assay in our study to detect any increase in the lung is possibly due to the cytotoxicity-related loss of damaged cells due to the relatively high mainstream smoke exposure concentration (72). We could identify only two cigarette smoke inhalation studies in the literature where the Comet assay was applied to lung tissue. Both studies found a positive effect, however, despite the high smoke concentrations (dilution around $1 / 7$, in our study $1 / 100$ ), the short daily exposure times (10 min and $1 \mathrm{~min}$, respectively) resulted in lower daily inhalation doses (time $\times$ concentration). Theoretical doses were $75 \%$ and $10 \%$, respectively $(73,69)$; however, it can be assumed that the actual doses were significantly lower, as rodents, if briefly exposed, are known to lower their respiratory minute volume drastically as a function of the irritative potency of the inhalant (74). A further explanation for the failure of the Comet assay to show smoke-related responses in our study could be the cross-linking effect of aldehydes in smoke, which can inhibit DNA migration preventing the detection of increases in strand breaks in the assay $(72,75)$. It is also known that some smoke constituents are more readily metabolized or metabolized differently in the lung than other smoke constituents (76-78). There are modifications of the Comet assay reported that might have improved the ability to detect DNA damages in our system, especially those induced by reactive oxygen species, including those via 8 -OHdG formation $(79,80)$. A decrease in liver and lung 8 -OHdG levels was observed in rats exposed to benzo $[a]-$ pyrene (a proxy for the polycyclic aromatic hydrocarbons in cigarette smoke), but this was accompanied by increased levels in bulky DNA adducts in these organs (81).

The only parameters where the combined effects of smoke exposure and biological aging are greater than both the agerelated increases alone and the smoke-related increases alone are DNA damage in the heart $(8-\mathrm{OHdG})$ and in the liver (Comet assay). However, considering the inherent variability of the assays, these data are compatible with the effects being even less than additive.

The strong increase in PCO seen in the lungs of old rats, though expected $(38,82)$, is somewhat surprising in light of the fact that both a smoke-related decrease in the young rats and an age-related decrease in air-exposed rats were seen. These decreases may be due to the organism's intrinsic defense metabolism, e.g., detoxification, or to the higher elimination of the damaged proteins, which may, in turn, be due to the higher smoke-related proteasome activity (83) observed in our study, or to the specificity of carbonylation of different proteins (84), as mentioned above. However, in the context of aging combined with smoking, a threshold may be exceeded which can lead to the deactivation of defense proteins, enabling even greater increases in damaged proteins, as indicated in smoke-exposed mice with a deficiency in one of the defense proteins (62). This deactivation of defense proteins remains to be further investigated in the context of smoke exposure.

Old calorie-restricted rats were used to test whether the expected reduction of oxidative burden due to caloric restriction (85) is reflected by a better resistance to cigarette smoke. However, for some parameters in the lung and lung macrophages (Comet assay, MDA, and CML), the calorierestricted rats appeared to be more vulnerable to smoke 
exposure. We speculate that this may be the result of reduced antioxidative repair efficiency, i.e., that the calorierestricted organism adapts to the lack of endogenous stress by economically reducing its defense mechanisms. By adapting in this way, the organism may no longer be able to cope efficiently with a sudden load of oxidative stress, such as subchronic cigarette smoke exposure. As it is know that adaptation may play a major role, a lifetime study could help to clarify the combined impact of caloric restriction; however, the direction of the responses might very well depend on the balance between the degree of caloric restriction and the strength of the induced oxidative stress. Within one publication, VUČEVIĆ et al. (86) reported a decrease in MDA and an increase in superoxide dismutase due to ethanol-induced oxidative stress after caloric restriction to 60 to $70 \%$ of ad libitum intake, but an effect in the opposite direction after restriction to $40-50 \%$.

\section{CONCLUSION}

With our experimental approach, we found evidence that the oxidative stress caused by aging and by smoking resulted in some common changes for several of the parameters tested. However, there is little evidence of synergistic effects. In order to obtain a more detailed understanding of the connection between aging and smoking and the possible acceleration of aging by cigarette smoke, future experiments should include the determination of dose- and time-dependency for both aging and smoke exposure. To increase the sensitivity of effects and better understand the possible mechanistic connections between aging and smoking, large-scale data sets (omics) and network-based approaches (87) and related approaches as discussed in " $21^{\text {st }}$ Century Toxicology" (88-91) may be worth pursuing.

\section{ACKNOWLEDGEMENTS}

Many thanks to the dedicated colleagues from Philip Morris Research Laboratories (PMRL) in Belgium and Germany who were involved in the study; and to Peter Voss, Anja Neisser, and Jennifer Torelli for their technical expertise. Special thanks also to Florian Meisgen for illuminating discussions.

\section{FUNDING}

This research was funded by Philip Morris International, Inc.; however, the opinions and conclusions of the researchers are their own and do not necessarily reflect Philip Morris International, Inc.'s position.

Thomas Meisgen, Ewald Roemer, Lynda L. Conroy, Jeroen Hostens, Andreas Humeny, Michaela Moehring, and Walter K. Schlage are employees or former employees of Philip Morris International, Inc.

This work was also supported in part by Philip Morris USA, Inc. prior to the spin-off of Philip Morris International, Inc. by Altria Group, Inc. on March 28, 2008.

\section{REFERENCES}

1. Doll, R., R. Peto, K. Wheatley, R. Gray, and I. Sutherland: Mortality in Relation to Smoking: 40 Years' Observations on Male British Doctors; BMJ 309 (1994) 901-911.

2. Forbes, W.F. and J.F. Gentleman: A Possible Similar Pathway Between Smoking-Induced Life Shortening and Natural Aging; J. Gerontol. 28 (1973) 302-311.

3. Grune, T. and K.J.A. Davies: Oxidative Processes in Aging; in: Handbook of the Biology of Aging, $5^{\text {th }}$ Edition, edited by E.J. Masoro and S.N. Austad, Academic Press, San Diego, CA, USA, 2001, p. 25-58.

4. Kregel, K.C. and H.J. Zhang: An Integrated View of Oxidative Stress in Aging: Basic Mechanisms, Functional Effects, and Pathological Considerations; Am. J. Physiol. Regul. Integr. Comp. Physiol. 292 (2007) R18-R36.

5. Beckman, K.B. and B.N. Ames: The Free Radical Theory of Aging Matures; Physiol. Rev. 78 (1998) 547-581.

6. Harman, D.: Free Radical Theory of Aging: An Update: Increasing the Functional Life Span; Ann. N. Y. Acad. Sci. 1067 (2006) 10-21.

7. Juránek, I., D. Nikitovic, D. Kouretas, A.W. Hayes, and A.M. Tsatsakis: Biological Importance of Reactive Oxygen Species in Relation to Difficulties of Treating Pathologies Involving Oxidative Stress by Exogenous Antioxidants; Food Chem. Toxicol. 61 (2013) 240-247.

8. Juránek, I. and Š. Bezek: Controversy of Free Radical Hypothesis: Reactive Oxygen Species - Cause or Consequence of Tissue Injury?; Gen. Physiol. Biophys. 24 (2005) 263-278.

9. Brand, M.D.: The Sites and Topology of Mitochondrial Superoxide Production; Exp. Gerontol. 45 (2010) 466-472.

10. Richter, C.: Oxidative Damage to Mitochondrial DNA and Its Relationship to Ageing; Int. J. Biochem. Cell. Biol. 27 (1995) 647-653.

11. Sohal, R.S. and M.J. Forster: Coenzyme Q, Oxidative Stress and Aging; Mitochondrion 7 Suppl. (2007) S103-S111.

12. Höhn, A., T. Jung, S. Grimm, and T. Grune: Lipofuscin-Bound Iron as a Major Intracellular Source of Oxidants: Role in Senescent Cells; Free Radic. Biol. Med. 48 (2010) 1100-1108.

13. Fontana, L. and S. Klein, Aging: Adiposity, and Calorie Restriction; JAMA 297 (2007) 986-994.

14. Masoro, E.J.: Influence of Caloric Intake on Aging and on the Response to Stressors; J. Toxicol. Environ. Health B Crit. Rev. 1 (1998) 243-257.

15. Church, D.F. and W.A. Pryor: Free-Radical Chemistry of Cigarette Smoke and Its Toxicological Implications; Environ. Health Perspect. 64 (1985) 111-126.

16. Wooten, J.B., S. Chouchane, and T.E. McGrath: Tobacco Smoke Constituents Affecting Oxidative Stress; in: Cigarette and Oxidative Stress, edited by B.B. Halliwell and H.E. Poulsen, Springer, Berlin, Heidelberg, New York, 2006, p. 5-46.

17. International Agency for Research on Cancer (IARC): Tobacco Smoke and Involuntary Smoking; IARC Monographs on the Evaluation of the Carcinogenic 
Risks of Chemicals to Humans Vol. 83, IARC, Lyon, France, 2004.

18. International Agency for Research on Cancer (IARC): Biological Data Relevant to the Carcinogenic Risk in Humans; in Tobacco Smoking, IARC Monographs On The Evaluation Of The Carcinogenic Risk Of Chemicals To Humans Vol. 38, IARC, Lyon, France 1986, p. 127-198.

19. Roemer, E., T.H. Ottmueller, H.J. Urban, C. BailletMignard: SKH-1 Mouse Skin Painting: A Short-Term Assay to Evaluate the Tumorigenic Activity of Cigarette Smoke Condensate; Toxicol. Lett. 192 (2010) 155-161.

20. Roemer, E., T.H. Ottmueller, V. Zenzen, S. Wittke, F. Radtke, I. Bianco, and R.A. Carchman: Cytotoxicity, Mutagenicity, and Tumorigenicity of Mainstream Smoke from Three Reference Cigarettes MachineSmoked to the Same Yields of Total Particulate Matter per Cigarette; Food Chem. Toxicol. 47 (2009) 1810-1818.

21. Schramke, H., T.J. Meisgen, F.J. Tewes, W. Gomm, and E. Roemer: The Mouse Lymphoma Thymidine Kinase Assay for the Assessment and Comparison of the Mutagenic Activity of Cigarette Mainstream Smoke Particulate Phase; Toxicology 227 (2006) 193-210.

22. Robinson, A.B., J.A. Stogsdill, J.B. Lewis, T.T. Wood, and P.R. Reynolds: RAGE and Tobacco Smoke: Insights into Modeling Chronic Obstructive Pulmonary Disease; Front. Physiol. 3 (2012) 301

23. Nicholl, I.D., A.W. Stitt, J.E. Moore, A.J. Ritchie, D.B. Archer, and R. Bucala: Increased Levels of Advanced Glycation Endproducts in the Lenses and Blood Vessels of Cigarette Smokers; Mol. Med. 4 (1998) 594-601.

24. Kasper, M. and R.H.W. Funk: Age-Related Changes in Cells and Tissues Due to Advanced Glycation End Products (AGEs); Arch. Gerontol. Geriatr. 32 (2001) 233-243.

25. Bayne, K.: Developing Guidelines on the Care and Use of Animals; Ann N Y Acad Sci 862 (1998) 105-110.

26. Diana, J.N. and A. Vaught: Research Cigarettes; University of Kentucky Printing Services, Lexington KY, USA, 1990.

27. International Organization for Standardization (ISO): ISO 3308. Routine Analytical Cigarette Smoking Machine - Definitions and Standard Conditions, $4^{\text {th }}$ Edition, ISO, Geneva, Switzerland, 2000.

28. Terpstra, P.M., A. Teredesai, P.M. Vanscheeuwijck, J. Verbeeck, G. Schepers, F. Radtke, P. Kuhl, W. Gomm, E. Anskeit, and G. Patskan: Toxicological Evaluation of an Electrically Heated Cigarette. Part 4: Subchronic Inhalation Toxicology; J. Appl. Toxicol. 23 (2003) 349-362.

29. Nyengaard, J.R.: Stereologic Methods and Their Application in Kidney Research; J. Am. Soc. Nephrol. 10 (1999) 1100-1123.

30. Bader, N., A. Bosy-Westphal, A. Koch, G. Rimbach, A. Weimann, H.E. Poulsen, and M.J. Müller: Effect of Hyperbaric Oxygen and Vitamin C and E Supplementation on Biomarkers of Oxidative Stress in Healthy Men; Br. J. Nutr. 98 (2007) 826-833.

31. Vasquez, M.Z.: Recommendations for Safety Testing with the in Vivo Comet Assay; Mutat. Res. 747 (2012)
$142-156$

32. Gil, L., W. Siems, B. Mazurek, J. Gross, P. Schroeder, P. Voss, and T. Grune: Age-Associated Analysis of Oxidative Stress Parameters in Human Plasma and Erythrocytes; Free Radic. Res. 40 (2006) 495-505.

33. Buss, H., T.P. Chan, K.B. Sluis, N.M. Domigan, and C.C. Winterbourn: Protein Carbonyl Measurement by a Sensitive ELISA Method; Free Radic. Biol. Med. 23 (1997) 361-366.

34. Voss, P., L. Horakova, M. Jakstadt, D. Kiekebusch, and T. Grune: Ferritin Oxidation and Proteasomal Degradation: Protection by Antioxidants; Free Radic. Res. 40 (2006) 673-683.

35. Kasper, M., D. Seidel, L. Knels, N. Morishima, A. Neisser, S. Bramke, and R. Koslowski: Early Signs of Lung Fibrosis After in Vitro Treatment of Rat Lung Slices with $\mathrm{CdCl}_{2}$ and TGF- $\beta 1$; Histochem. Cell. Biol. 121 (2004) 131-140.

36. Kalousová, M., T. Zima, V. Tesař, S. Dusilová-Sulková, and J. Skrha: Advanced Glycoxidation End Products in Chronic Diseases - Clinical Chemistry and Genetic Background; Mutat. Res. 579 (2005) 37-46.

37. Romano, A.D., G. Serviddio, A. de Matthaeis, F. Bellanti, and G. Vendemiale: Oxidative Stress and Aging; J. Nephrol. 23 Suppl. 15 (2010) S29-S36.

38. Breusing, N., J. Arndt, P. Voss, N. Bresgen, I. Wiswedel, A. Gardemann, W. Siems, and T. Grune: Inverse Correlation of Protein Oxidation and Proteasome Activity in Liver and Lung; Mech. Ageing Dev. 130 (2009) 748-753.

39. Ribarič, S.: Diet and Aging; Oxid. Med. Cell. Longev. (2012) 741468.

40. Kim, L.G., J. Adamson, and S. Ebrahim: Influence of Life-Style Choices on Locomotor Disability, Arthritis and Cardiovascular Disease in Older Women: Prospective Cohort Study; Age Ageing 42 (2013) 696-701.

41. Burke, G.L., A.M. Arnold, D.E. Bild, M. Cushman, L.P. Fried, A. Newman, C. Nunn, J. Robbins, and for the CHS Collaborative Research Group: Factors Associated with Healthy Aging: The Cardiovascular Health Study; J. Am. Geriatr. Soc. 49 (2001) 254-262.

42. Csordas, A., G. Wick, G. Laufer, and D. Bernhard: An Evaluation of the Clinical Evidence on the Role of Inflammation and Oxidative Stress in Smoking-Mediated Cardiovascular Disease; Biomark. Insights 3 (2008) 127-139.

43. Goodson, N.J., D.P.M. Symmons, D.G.I. Scott, D. Bunn, M. Lunt, and A.J. Silman: Baseline Levels of CReactive Protein and Prediction of Death from Cardiovascular Disease in Patients with Inflammatory Polyarthritis: A Ten-Year Followup Study of a Primary CareBased Inception Cohort; Arthritis. Rheum. 52 (2005) 2293-2299.

44. Kapetanovic, M.C., E. Lindqvist, P. Geborek, T. Saxne, and K. Eberhard: Long-Term Mortality Rate in Rheumatoid Arthritis Patients with Disease Onset in the 1980s; Scand. J. Rheumatol. 40 (2011) 433-438.

45. Turesson, C., R.L. McClelland, T.J.Christianson, and E.L. Matteson: Severe Extra-Articular Disease Manifestations Are Associated with an Increased Risk of First Ever Cardiovascular Events in Patients with Rheumatoid Arthritis; Ann. Rheum. Dis. 66 (2007) 70-75. 
46. Bernhard, D., C. Moser, A. Backovic, and G. Wick: Cigarette Smoke - An Aging Accelerator?; Exp. Gerontol. 42 (2007) 160-165.

47. Ristow, M. and S. Schmeisser: Extending Life Span by Increasing Oxidative Stress; Free Radic. Biol. Med. 51 (2011) 327-336.

48. Salmon, A.B., A. Richardson, and V.I. Pérez: Update on the Oxidative Stress Theory of Aging: Does Oxidative Stress Play a Role in Aging or Healthy Aging?; Free Radic. Biol. Med. 48 (2010) 642-655.

49. Gems, D. and L. Partridge: Genetics of Longevity in Model Organisms: Debates and Paradigm Shifts; Annu. Rev. Physiol. 75 (2013) 621-644.

50. Kim, D.-H., Y.-S. Suh, and K.-C. Mun: Tissue Levels of Malondialdehyde after Passive Smoke Exposure of Rats for a 24-Week Period; Nicotine Tob. Res. 6 (2004) 1039-1042.

51. Kocyigit, A., S. Selek, H. Celik, and M. Dikilitas: Mononuclear Leukocyte DNA Damage and Oxidative Stress: The Association with Smoking of Hand-Rolled and Filter-Cigarettes; Mutat. Res. 721 (2011) 136-141.

52. Murărescu, E.D., R. Iancu, and M.S. Mihailovici: Morphological Changes Positive Correlates with Oxidative Stress in COPD. Preliminary Data of an Experimental Rat Model - Study and Literature Review; Rom. J. Morphol. Embryol. 48 (2007) 59-65.

53. Nielsen, F., B.B. Mikkelsen, J.B. Nielsen, H.R. Andersen, and P. Grandjean: Plasma Malondialdehyde as Biomarker for Oxidative Stress: Reference Interval and Effects of Life-Style Factors; Clin. Chem. 43 (1997) 1209-1214.

54. Pekmez, H., I. Kus, N. Colakoglu, M. Ogeturk, H. Ozyurt, A.O. Turkoglu, and M. Sarsilmaz: The Protective Effects of Caffeic Acid Phenethyl Ester (CAPE) Against Liver Damage Induced by Cigarette Smoke Inhalation in Rats; Cell. Biochem. Funct. 25 (2007) 395-400.

55. Ungvari, Z., A. Csiszar, D. Sosnowska, E.E. Philipp, C.M. Campbell, P.R. McQuary, T.T. Chow, M. Coelho, E.S. Didier, S. Gelino, M.A. Holmbeck, I. Kim, E. Levy, W.E. Sonntag, P.W. Whitby, S.N. Austad, and I. Ridgway: Testing Predictions of the Oxidative Stress Hypothesis of Aging Using a Novel Invertebrate Model of Longevity: The Giant Clam (Tridacna Derasa); J. Gerontol. A Biol. Sci. Med. Sci. 68 (2013) 359-367.

56. Kaneko, T., S. Tahara, and M. Matsuo: Retarding Effect of Dietary Restriction on the Accumulation of 8Hydroxy-2'-deoxyguanosine in Organs of Fischer 344 Rats during Aging; Free Radic. Biol. Med. 23 (1997) 76-81.

57. Sohal, R.S., S. Agarwal, M. Candas, M.J. Forster, and H. Lal: Effect of Age and Caloric Restriction on DNA Oxidative Damage in Different Tissues of C57BL/6 Mice; Mech. Ageing Dev. 76 (1994) 215-224.

58. Vyskočilová, E., B. Szotáková, L. Skálová, H. Bártíková, J. Hlavácová, and I. Boušová: Age-Related Changes in Hepatic Activity and Expression of Detoxification Enzymes in Male Rats; Biomed. Res. Int. (2013) 408573.

59. Davies, S.M.K., A. Poljak, M.W. Duncan, G.A. Smythe, and M.P. Murphy: Measurements of Protein Carbonyls, ortho- and meta-Tyrosine and Oxidative
Phosphorylation Complex Activity in Mitochondria from Young and Old Rats; Free Radic. Biol. Med. 31 (2001) 181-190.

60. Goto, S., R. Takahashi, Z. Radak, and R. Sharma: Beneficial Biochemical Outcomes of Late-Onset Dietary Restriction in Rodents; Ann. N. Y. Acad. Sci. 1100 (2007) 431-441.

61. Youngman, L.D., J.Y. Park, and B.N. Ames: Protein Oxidation Associated with Aging is Reduced by Dietary Restriction of Protein or Calories; Proc. Natl. Acad. Sci. U. S. A. 89 (1992) 9112-9116.

62. Sato, T., K. Seyama, Y. Sato, H. Mori, S. Souma, T. Akiyoshi, Y. Kodama, T. Mori, S. Goto, K. Takahashi, Y. Fukuchi, N. Maruyama, and A. Ishigami: Senescence Marker Protein-30 Protects Mice Lungs from Oxidative Stress, Aging, and Smoking; Am. J. Respir. Crit. Care Med. 174 (2006) 530-537.

63. Jana, C.K., N. Das, and R.S. Sohal: Specificity of AgeRelated Carbonylation of Plasma Proteins in the Mouse and Rat; Arch. Biochem. Biophys. 397 (2002) 433-439.

64. Organisation for Economic Co-operation and Development (OECD): Test No. 413: Subchronic Inhalation Study: 90-Day Study; OECD Guidelines for the Testing of Chemicals, Section 4, OECD Publishing, Paris, 2009.

65. Vanscheeuwijck, P.M., A. Teredesai, P.M. Terpstra, J. Verbeeck, P. Kuhl, B. Gerstenberg, S. Gebel, and E.L. Carmines: Evaluation of the Potential Effects of Ingredients Added to Cigarettes. Part 4: Subchronic Inhalation Toxicity; Food Chem. Toxicol. 40 (2002) 113-131.

66. Müller, T. and S. Gebel: The Cellular Stress Response Induced by Aqueous Extracts of Cigarette Smoke is Critically Dependent on the Intracellular Glutathione Concentration; Carcinogenesis 19 (1998) 797-801.

67. Hoffmann, H., C. Isner, J. Högel, and G. Speit: Genetic Polymorphisms and the Effect of Cigarette Smoking in the Comet Assay; Mutagenesis 20 (2005) 359-364.

68. Fraga, C.G., M.K. Shigenaga, J.W. Park, P. Degan, and B.N. Ames: Oxidative Damage to DNA During Aging: 8-Hydroxy-2'-deoxyguanosine in Rat Organ DNA and Urine; Proc. Natl. Acad. Sci. U. S. A. 87 (1990) 4533-4537.

69. Tsuda, S., N. Matsusaka, S. Ueno, N. Susa, and Y.F. Sasaki: The Influence of Antioxidants on Cigarette Smoke-Induced DNA Single-Strand Breaks in Mouse Organs: A Preliminary Study with the Alkaline Single Cell Gel Electrophoresis Assay; Toxicol. Sci. 54 (2000) 104-109.

70. Weber, S., M. Hebestreit, T. Wilms, L.L. Conroy, and G. Rodrigo: Comet Assay and Air-Liquid Interface Exposure System: A New Combination to Evaluate Genotoxic Effects of Cigarette Whole Smoke in Human Lung Cell Lines; Toxicol. In Vitro 27 (2013) 1987-1991.

71. Lima, P.H.O., Y.K. Sinzato, M. da Silva S. de Souza, M.G. Braz, M.V.C. Rudge, and D.C. Damasceno: Evaluation of Level of DNA Damage in Blood Leukocytes of Non-Diabetic and Diabetic Rat Exposed to Cigarette Smoke; Mutat. Res. 628 (2007) 117-122.

72. Vasquez, M.Z.: Combining the in Vivo Comet and Micronucleus Assays: A Practical Approach to Genotoxicity Testing and Data Interpretation; Mutagenesis 25 (2010) 187-199. 
73. Villard, P.-H., E.M. Seree, J.-L. Re, M. De Meo, Y. Barra, L. Attolini, G. Dumenil, J. Ctalin, A. Durand, and B. Lacarelle: Effects of Tobacco Smoke on the Gene Expression of the Cyp 1a, Cyp2b, Cyp2e, and Cyp3a Subfamilies in Mouse Liver and Lung: Relation to Single Strand Breaks of DNA; Toxicol. Appl. Pharmacol. 148 (1998) 195-204.

74. Alarie, Y.: Computer-Based Bioassay for Evaluation of Sensory Irritation of Airborne Chemicals and Its Limit of Detection; Arch. Toxicol. 72 (1998) 277-282.

75. Grafström, R.C., J.M. Dypbukt, K. Sundqvist, L. Atzori, I. Nielsen, R.D. Curren, and C.C. Harris: Pathobiological Effects of Acetaldehyde in Cultured Human Epithelial Cells and Fibroblasts; Carcinogenesis 15 (1994) 985-990.

76. Ben-Zaken Cohen, S., P.D. Paré, S.F. Man, and D.D. Sin: The Growing Burden of Chronic Obstructive Pulmonary Disease and Lung Cancer in Women: Examining Sex Differences in Cigarette Smoke Metabolism; Am. J. Respir. Crit. Care Med. 176 (2007) 113-120.

77. Koyama, H. and D.M. Geddes: Genes, Oxidative Stress, and the Risk of Chronic Obstructive Pulmonary Disease; Thorax 53 Suppl. 2 (1998) S10-S14.

78. Nishikawa, A., Y. Mori, I.-S. Lee, T. Tanaka, and M. Hirose: Cigarette Smoking, Metabolic Activation and Carcinogenesis; Curr Drug Metab 5 (2004) 363-373.

79. Collins, A.R.: Measuring Oxidative Damage to DNA and Its Repair with the Comet Assay; Biochim. Biophys. Acta 1840 (2014) 794-800.

80. Collins, A.R., V.L. Dobson, M. Dusinská, G. Kennedy, and R. Stétina: The Comet Assay: What Can It Really Tell Us?; Mutat. Res. 375 (1997) 183-193.

81. Briedé, J.J., R.W.L. Godschalk, M.T.G. Emans, T.M.C.M. de Kok, E. van Agen, J.M.S. van Maanen, F.-J. van Schooten, and J.C.S. Kleinjans: In Vitro and in Vivo Studies on Oxygen Free Radical and DNA Adduct Formation in Rat Lung and Liver During Benzo $[a]$ pyrene Metabolism; Free Radic. Res. 38 (2004) 995-1002.

82. Lee, H.C., M.L. Lim, C.Y. Lu, V.W. Liu, H.J. Fahn, C. Zhang, P. Nagley, and Y.H. Wei: Concurrent Increase of Oxidative DNA Damage and Lipid Peroxidation Together with Mitochondrial DNA Mutation in Human Lung Tissues During Aging - Smoking Enhances Oxidative Stress on the Aged Tissues; Arch. Biochem. Biophys. 362 (1999) 309-316.

83. Torres, C.A. and V.I. Perez: Proteasome Modulates Mitochondrial Function During Cellular Senescence; Free Radic. Biol. Med. 44 (2008) 403-414.
84. Baraibar, M.A., R. Ladouce, and B. Friguet: Proteomic Quantification and Identification of Carbonylated Proteins upon Oxidative Stress and during Cellular Aging; J. Proteomics 92 (2013) 63-70.

85. Kolovou, G.D., V. Kolovou, and S. Mavrogeni: We Are Ageing; Biomed. Res. Int. (2014) 808307.

86. Vučević, D., Mladenović, M. Ninković, V. Alksić, M.N. Stanković, M. Stanković, B. Jorgačević, R.J. Vukičević, and T. Radosavljević: The Effects of Caloric Restriction Against Ethanol-Induced Oxidative and Nitrosative Cardiotoxicity and Plasma Lipids in Rats; Exp. Biol. Med. (Maywood) 238 (2013) 1396-1405.

87. Hoeng, J., R. Deehand, D. Pratt, F. Martin, A. Sewer, T.M. Thomson, D.A. Drubin, C.A. Waters, D. de Graaf, and M.C. Peitsch: A Network-Based Approach to Quantifying the Impact of Biologically Active Substances; Drug. Discov. Today. 17 (2012) 413-418.

88. Hartung, T.: A Toxicology for the $21^{\text {st }}$ Century Mapping the Road Ahead; Toxicol. Sci. 109 (2009) 18-23.

89. Mahadevan, B., R.D. Snyder, M.D. Waters, R.D. Benz, R.A. Kemper, R.R. Tice, and A.M. Richard: Genetic Toxicology in the $21^{\text {st }}$ Century: Reflections and Future Directions; Environ. Mol. Mutagen. 52 (2011) 339-354.

90. Stephens, M.L., C. Barrow, M.E. Andersen, K. Boekelheide, P.L. Carmichael, M.P. Holsapple, and M. Lafranconi: Accelerating the Development of $21^{\text {st }}$-Century Toxicology: Outcome of a Human Toxicology Project Consortium Workshop; Toxicol. Sci. 125 (2012) 327-334.

91. Rowlands, J.C., M. Sander, and J. Bus: Future Tox: Building the Road for $21^{\text {st }}$ Century Toxicology and Risk Assessment Practices; Toxicol. Sci. 137 (2013) 269-277.

Corresponding author:

Ewald Roemer

Philip Morris International R\&D

Rue des Usines 90

2000 Neuchatel, Switzerland

Phone: +4132888 3207

Email: ewald.roemer@pmi.com 